\title{
0099. Nitrite reductase activity during sepsis
}

\author{
V Simon ${ }^{1,2^{*}}$, A Dyson $^{1}, M$ Minnion ${ }^{3}$, M Feelisch $^{3}$, M Singer $^{1}$ \\ From ESICM LIVES 2014 \\ Barcelona, Spain. 27 September - 1 October 2014
}

\section{Introduction}

Nitric oxide (NO) excess is considered to be the main cause of hypotension in sepsis. Research has mainly focussed upon NO production by isoforms of NO synthase (NOS). However, alternative pathways may make an important contribution, including nitrite $\left(\mathrm{NO}_{2}{ }^{-}\right)$reduction by the reductase activity possessed by numerous heme- and pterin-based enzymes. The temporal contribution of these pathways to NO production in sepsis is currently unclear.

\section{Objectives}

To investigate changes in nitrite reductase activity during sepsis.

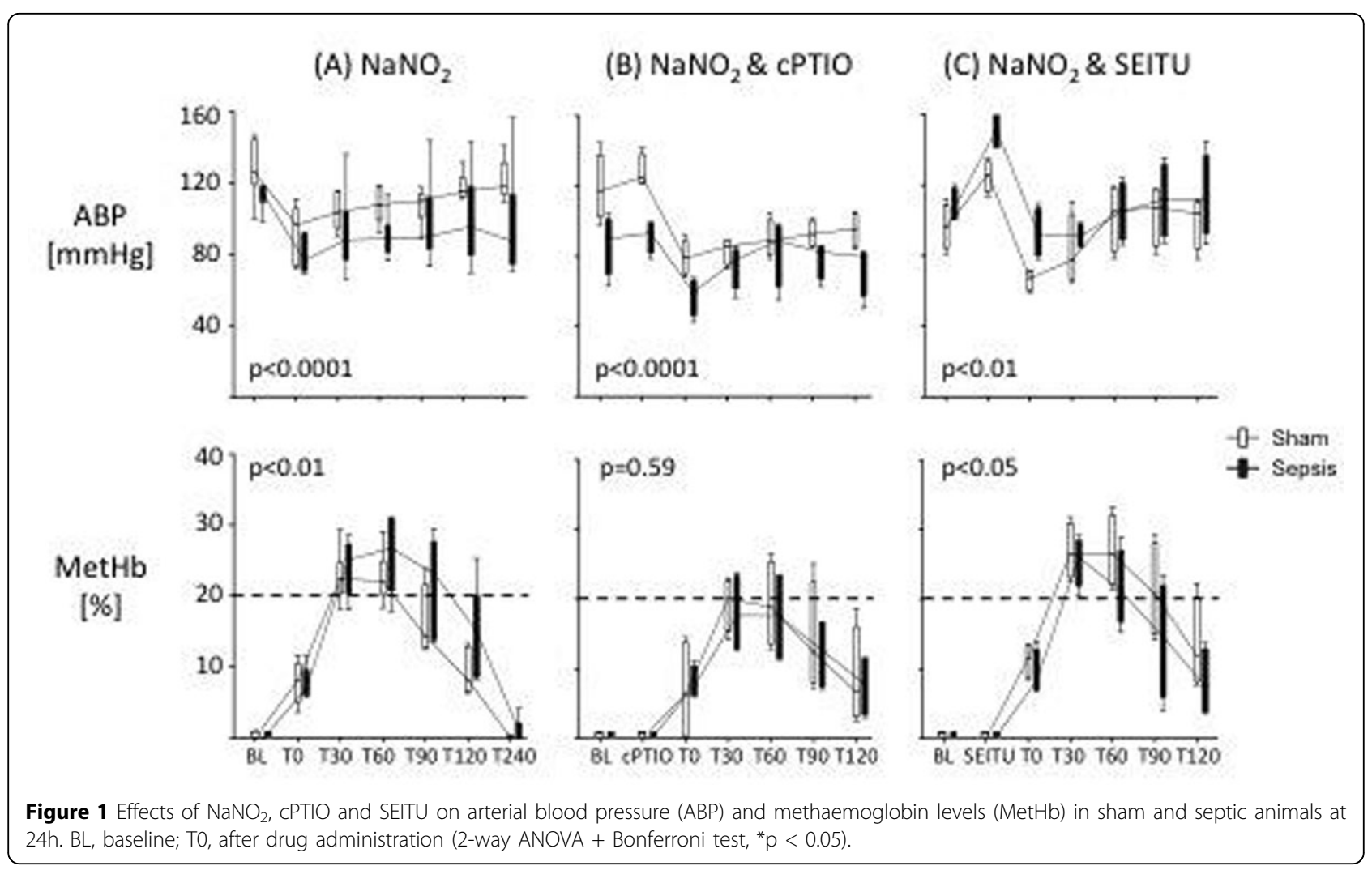

'University College London Hospital NHS Foundation Trust, Bloomsbury

Institute of Intensive Care Medicine, London, UK

Full list of author information is available at the end of the article

(c) 2014 Simon et al; licensee Springer. This is an Open Access article distributed under the terms of the Creative Commons Attribution License (http://creativecommons.org/licenses/by/2.0), which permits unrestricted use, distribution, and reproduction in any medium, provided the original work is properly cited. 


\section{Methods}

Male Wistar rats (approx 300g wt) with tunnelled right jugular venous and left common carotid arterial lines in situ received i.p. injection of either faecal slurry (septic) or n-saline (sham). Fluid (1:1 mixture of $5 \%$ glucose/ Hartmann`s; $10 \mathrm{ml} / \mathrm{kg} / \mathrm{h}$ ) was started $2 \mathrm{~h}$ later. At either $6 \mathrm{~h}$ or $24 \mathrm{~h}$, rats were anaesthetized and tracheotomized. After stabilization, measurements were made of haemodynamics (blood pressure, echocardiography) and methaemoglobinaemia (oxidation of $\mathrm{Hb}$ to the $\mathrm{Fe}^{3+}$ form induced by NO or nitrite) before and after a $25 \mathrm{ml} / \mathrm{kg}$ bolus fluid challenge (BL, baseline) to ensure adequate LV filling. Animals then received (A) a single dose of sodium nitrite $\left(\mathrm{NaNO}_{2}, 15 \mathrm{mg} / \mathrm{kg}\right.$ i.v. $)$ to stimulate nitrite reductase activity, (B) a combination of $\mathrm{NaNO}_{2}$ and the NO-scavenger cPTIO (3.4mg/kg i.v.) or (C) a combination of $\mathrm{NaNO}_{2}$ and the non-specific NOS-inhibitor SEITU (1mg/kg i.v.). Recordings were made over the next $2-4 \mathrm{~h}$ prior to sacrifice.

\section{Results}

At $6 \mathrm{~h}$, there was no significant difference between groups (data not shown). However, at 24h, septic animals showed a greater fall in $\mathrm{BP}$ following $\mathrm{NaNO}_{2}$ with a longer time to recovery, signifying increased nitrite reductase activity (Fig 1A). After scavenging of free NO (1B) and NOS inhibition (1C), both groups showed an initial rise in BP, followed by a significant fall with $\mathrm{NaNO}_{2}$. However, on removal of NO there was no prolonged $\mathrm{BP}$ recovery time in the septic animals. Baseline methaemoglobinaemia was low in both control and septic animals at $24 \mathrm{~h}$ and increased markedly with $\mathrm{NaNO}_{2}$, again with a longer recovery time in septic animals. This rise was blunted by pre-treatment with the NO scavenger, c-PTIO, but not by SEITU though SEITU did prevent the delayed normalization in metHb levels .

\section{Conclusions}

In this rat model, increased nitrite reductase activity was apparent during established $(24 \mathrm{~h})$ sepsis, but not at an early (6h) timepoint. The clinical relevance of this finding needs to be elucidated.

\section{Grant acknowledgment}

Internal lab funds and salary support from University Hospital Aachen.

\footnotetext{
Authors' details

${ }^{1}$ University College London Hospital NHS Foundation Trust, Bloomsbury Institute of Intensive Care Medicine, London, UK. ${ }^{2}$ University Hospital Aachen, Intensive Care Medicine, Aachen, Germany. ${ }^{3}$ University of Southampton, Faculty of Medicine, Southampton, UK.
}

Published: 26 September 2014
doi:10.1186/2197-425X-2-S1-P10

Cite this article as: Simon et al:: 0099. Nitrite reductase activity during sepsis. Intensive Care Medicine Experimental 2014 2(Suppl 1):P10.

\section{Submit your manuscript to a SpringerOpen ${ }^{\circ}$ journal and benefit from:}

- Convenient online submission

- Rigorous peer review

- Immediate publication on acceptance

- Open access: articles freely available online

- High visibility within the field

- Retaining the copyright to your article

Submit your next manuscript at $>$ springeropen.com 